\title{
Primary central nervous system lymphoma
}

INSERM

\section{Source}

INSERM. (1999). Orphanet: an online rare disease and orphan drug data base. Primary central nervous system lymphoma. ORPHA:46135

Primary central nervous system lymphoma (PCNSL) is a rare nervous system tumor, predominantly due to diffuse large B-cell lymphoma, that involves brain, leptomeninges, eyes, or rarely spinal cord, in the absence of systemic diffusion at the time of diagnosis. It is characterized by a solitary tumor that, depending on its location, can lead to a variety of symptoms such as headache, nausea, vomiting (and other signs of raised intracranial pressure), focal neurologic deficits, neuropsychiatric and ocular symptoms, seizures and personality changes. 